\title{
DEDIKASI GURU DITINJAU DARI PSYCHOLOGYCAL WELL-BEING
}

\author{
Sulistiana ${ }^{1}$ \\ Universitas Muhammadiyah Gresik
}

\begin{abstract}
The purpose of this research is to find out the influence of psychological well-being toward teacher's dedication of SMAN " $X$ " in Gresik. The population is 62 teachers SMAN " $X "$. Both of variables was measured by likert scale with 5choices.The Reliabilityof Psychological well-being scale is 0.888. The Reliability of teacher's dedication scale is 0,781. The technik of analysis data used The of value $F=60,658, p=0,005<0,05$, it indicated that regresssion line equation $y=25.023+357 x$ is significantly. The value $t=$ 7,788, $p=0,005<0,05$, with the result Ho is rejected and Ha is accepted. It means that psychological well-being affect the teacher's dedication.R Square (coefficient of determination) 0,503 inform that the effective contribution of psychological well-being toward teacher's dedication 50,3\%, while the rest 49,7\% influenced by other variable not examined.
\end{abstract}

Keywords: Psychological Well-Being, Teacher'sDedication

\begin{abstract}
Abstrak
Penelitian ini untuk mengetahui gambaran tingkat psychological well-being terhadap tingkat dedikasi guru SMAN "X" di Gresik.Tipe penelitian korelasional dengan pendekatan kuantitatif. Populasi penelitian adalah berjumlah 62 guru SMAN Xdi Gresik. yang digunakan adalah seluruh GuruSMAN "X" sejumlah 62 orang.Kedua variabel diukur dengan skala likert.Koefisien reliabilitasskalapsychological well-being sebesar 0,888 . Koefisien reliabilitas skala dedikasi guru sebesar 0,781. Data penelitian diolah dengan teknik regresi sederhana. Nilai $\mathrm{F}=60.658$ mengindikasikan persamaam garis regresi $y=25.023+357 x$ adalah secara statistik signifikan. Nilai t hitung $=7.788$, dengan nilai $\mathrm{p}=0,00<0,05$, sehinggaHo ditolak dan Ha diterima. Hal itu berarti psychological well-beingberpengaruh secara signifikan terhadap dedikasi guru.Nilai $R$ Square sebesar 0,503 menginformasikan bahwa sumbangan tingkat psychological well-being terhadap tingkat dedikasi guru sebesar 50,3\%, sedangkan sisanya 49,7\% dipengaruhi variabel lain yang tidak diteliti.
\end{abstract}

Kata kunci: Psychological Well-Being, Dedikasi Guru

\section{Pendahuluan}

Pasal 1 Undang-Undang Sistem Pendidikan Nasional Nomor 20 tahun 2003 menyatakan"pendidikan nasional berfungsi mengembangkan kemampuan dan membentuk watak serta peradaban bangsa yang bermartabat dalam rangka mencerdaskan kehidupan bangsa, bertujuan untuk berkembangnya potensi peserta didik agar menjadi manusia yang beriman dan bertakwa kepada Tuhan yang Maha Esa, berahlak mulia, sehat, berilmu, cakap, kreatif, mandiri, dan menjadi warga negara yang demokratis serta bertanggung jawab".Tentunya guru memegang

1email : sulistiana_34@yahoo.com

Prodi S1 Psikologi Fakultas Psikologi Universitas Muhammadiyah Gresik

Jalan Sumatra No.101 Gresik Kota Baru (GKB) Gresik Jawa Timur

Psikosains, Vol. 13, No.1,Februari 2018, hal. 79-92 
peranan penting dalam menentukan pencapaian tujuan pendidikan nasional, karena bagaimana pun baiknya kurikulum, atau bagaimana pun juga memadainya sarana pendidikan, bila gurunya tidak mampu memainkan perannya dengan baik, maka kegiatan pendidikan tidak akan berkembang sebagaimana diharapkan (Mulyasana, D. 2015:6).

Guru adalah ujung tombak dalam proses belajar mengajar. Guru berinteraksi langsung dengan siswa dalam kelas. Guru memegang peranan sangat penting dalam membuat siswa mengerti dan paham mengenai mata pelajaran yang diajarkan. Sekolah sebagai institusi pendidikan membutuhkan guru yang tidak hanya berfungsi sebagai pengajar yang mengajarkan mata pelajaran tertentu kepada peserta didiknya, tetapi jugasebagai pendidik yang memberikan bekal pengetahuan kepada siswanya mengenai etika, kemampuan survive dalam hidup, moral, empati, kreasi dan sebagainya (Fathurrohman, P. 2012:13).Atau dengan perkataan lain, guru mempunyai pengaruh terhadap perubahan perilaku peserta didik (Uno, B.H. 2012:17).D. Grambs dan C. Morris Mc Clareberpendapat "Teacher are those persons who consciously direct the experiences and behavior of an individual so that education takes places" (Uno, B.H. 2012:15).

Subini(2012:49-50) menyatakan bahwa banyak faktor yang membuat seseorang memutuskan untuk menjadi guru, tetapi idealnya menjadi guru adalah panggilan hati nurani. Menjadi guru berdasarkan tuntutan pekerjaan adalah suatu perbuatan yang mudah, namun menjadi guru berdasarkan panggilan jiwa tidaklah muda. Guru lebih banyak dituntut sebagai suatu pengabdian kepada anak didik daripada tuntutan pekerjaan dan materi. Kepribadian guru akan tercermin dalam sikap dan perbuatannya dalam membina dan membimbing anak didik.Untuk itu guru dituntut memiliki pengabdian yang tinggi dalam membelajarkan anak didik (Rahman, M. dan Amri, S. 2014-200).

Kamus Besar Bahasa Indonesia menyebutkan bahwa pengabdian adalah dedikasi. Çağrı Tuğrul Martmenegaskan masalah dedikasi dalamInternational Journal(January 2013)bahwasalah satu hal yang menjadi faktor terpenting dalam pengembangan antusiasme mengajar adalah dengan adanya komitmen terus menerus dari seorang guru, dan dedikasi terhadap proses belajar mengajar siswa. Zainal, A. (2015) memaparkan hasilpenelitiannya bahwa MAN Suruh memiliki guru-guru yang berdedikasi. Wujud dedikasinya adalah; 1) Adanya rasa kesediaan guru-guru untuk selalu berkorban baik pengorbanan tenaga, pikiran dan waktu demi meningkatkan mutu pendidikan; 2)Tumbuhnya rasa keinginan guru untuk memberikan yang terbaik dalam meningkatkan mutu pendidikan, 3) Guru MAN Suruh secara tidak langsung memiliki jiwa yang tangguh dalam meningkatkan mutu pendidikan.

Zahroh, A.(2015:39)menyatakan bahwa melalui dedikasi yang dimiliki, seorang guru tidak akan menjadikan profesinya sebagai pekerjaan yang hanya digunakan untuk mencari keuntungan material atau finansial saja, melainkan lebih 
kepada bentuk dan wujud kecintaan terhadap pekerjaan tersebut. Hal tersebut, dengan sendirinya menimbulkan jiwa pengabdian yang terus menyala bagai api unggun.

Data lain peneliti himpun melalui wawancara dengan para wakil kepala SMAN "X" dengan menggunakan media WhatsApp. Peneliti mengajukan pertanyaan pada tanggal yang sama yakni 17 April 2016, dengan pertanyaan yang sama terhadap keempat Wakasek SMAN "X", sebagaimana terdapat pada tabel 1 . dibawah.

Tabel 1. Data Hasil Wawancara dengan Para Wakil Kepala Sekolah

\begin{tabular}{|c|c|}
\hline Jawaban & $\begin{array}{l}\text { Bagaimana pendapat bapak dan ibu tentang dedikasi guru-guru di SMAN } \\
\text { "X" ini?" }\end{array}$ \\
\hline Wakasek A & $\begin{array}{l}\text { "Saya mengamati rata-rata guru sekolah ini memiliki tanggung jawab terhadap } \\
\text { siswanya, baik dari segi pengelolaan kelasnya maupun kualifikasi } \\
\text { akademiknya." }\end{array}$ \\
\hline Wakasek B & $\begin{array}{l}\text { "Menurutku, dedikasi teman-teman SMAN "X" ini cukup tinggi. Indikasinya } \\
\text { ya capaian prestasi yang telah dicapai siswa selama ini. Usia SMAN "X" } \\
\text { ini masih relatif muda tetapi tampilannya sangat kompetitif sekali." }\end{array}$ \\
\hline Wakasek C & $\begin{array}{l}\text { "Dedikasi masih kurang karena banyak guru yang hanya model mengajarnya } \\
\text { habis mengajar terus pulang..." }\end{array}$ \\
\hline Wakasek D & $\begin{array}{l}\text { "Dedikasi guru sedang aja. Kinerja turun dibanding awal berdiri. Sebabnya } \\
\text { banyak hal....." }\end{array}$ \\
\hline
\end{tabular}

Berdasarkan tabel 1 maka dapat diketahui bahwa dua orang wakil kepala sekolah menilai dedikasi guru masih kurang, bahkan satu orang wakasek menilai dedikasi menurun jika dibandingkan awal berdirinya SMAN $\mathrm{X}$ tersebut. Sementara berdasarkan data yang bersumberpada hasil catatan layanan konsultasi Guru BK terhadap keluhan 5 siswa sebagaimana pada tabel 2. dapat diketahui bahwa beberapa kompetensi yang seharusnya dimiliki belum sepenuhnya dimiliki beberapa guru. Sebagai contoh keluhan siswa 1 dan 2 berkaitan dengan kurang optimalnya kompetensi pedagogik guru, hal tersebut terlihat dari kemampuan menjelaskan materi dan menjawab pertanyaan yang tidak efektif, meninggalkan kelas pada jam pelajaran, memberikan soal ujian tidak sesuai dengan materi yang diajarkan. Sementara keluhan siswa 3 menunjukkan kompetensi pribadi yang kurang memadai yang ditunjukkan mudah menyampaikan kata-kata meyakitkan kepada siswa. Perilaku bermain HP dan sering menerima telpon pada saat mengajar di kelas menunjukkan kompetensi sosial guru yang kurang sebagaimana keluhan yang disampaikan siswa 4. Beberapa keluhan siswa tersebut 4 menunjukkan kinerja dan kompetensi guru yang belum memadai. 
Tabel 2. Catatan Layanan Konsultasi Guru BK Terhadap Keluhan Siswa

\section{KELUHAN SISWA}

\begin{tabular}{cl}
\hline Siswa & "Gurunya memang rajin dan baik, tetapi kalau menerangkan sering mbulet \\
1 & $\begin{array}{l}\text { dan masih mikir saat saya atau teman yang lain menanyakan materi yang } \\
\text { berkaitan dengan yang diajarkan. Jawabannya juga mbulet dan tidak } \\
\text { meyakinkan, jadi kita tetap tidak mengerti. Kalau kita mencoba bertanya }\end{array}$ \\
& $\begin{array}{l}\text { lagi di ruang guru, tampak tidak berkenan membuat kita jadi kapok" } \\
\text { (wwcr/08.09.15/Skl). }\end{array}$ \\
Siswa & "Sering kosong dan hanya diberi tugas. Saat akan ulangan kita disuruh foto \\
2 & kopi materi yang akan dikeluarkan pada ulangan. Jadi bab yang ada di \\
& ulangan belum diajarkan tetapi hanya diberi rangkuman untuk dipelajari \\
Siswa & "Kalau berbicara sering menyakitkan. Mudah mengumpat dan mengatakan \\
3 & $\begin{array}{l}\text { siswa tidak bisa diatur. Malas setiap beliau mengajar karena orangnya sok } \\
\text { pintar dan sok wibawa..." (wwcr/20.10.15/Skl). }\end{array}$ \\
Siswa & "Kalau sedang mengajar sering terima telepon. Katanya urusan bisnis. \\
4 & $\begin{array}{l}\text { Mengganggu sekali. Saat kita mengerjakan tugas yang diberikan, gurunya } \\
\text { main game dan tertawa-tawa sendiri. Jadi enggan untuk bertanya karena }\end{array}$ \\
Siswa & $\begin{array}{l}\text { "Orunya fokus pada HandPhone saja..." (wwcr/26.10.15/Skl). } \\
5\end{array}$ \\
& $\begin{array}{l}\text { Menerangkannya juga lumayan enak. Sayang saat naik kelas, tidak } \\
\text { mengajar di kelas kami lagi" (wwcr/3.11.15/Skl). }\end{array}$
\end{tabular}

Kenyataan pada sekolah SMAN"X" menunjukkan bahwa ada kesenjangan dari gambaran ideal yang seharusnya guru memiliki dedikasi dalam menjalankan tugas dan kewajibannya namun kenyataannya masih belum sepenuhnya terwujud. Oleh karena itu peneliti tertarik untuk meneliti faktor yang mempengaruhi dedikasi guru dalam hal ini adalah Psychological Well Being guru. Antara lain indikator Psychological Well Being yaitu memiliki tujuan hidup dan penguasaan terhadap lingkungan. Hal inilah yang bisa mengarahkan perilaku dan tindakan individu untuk menentukan pilihan perilaku atau keputusan, termasuk memilih suatu profesi dan menunjukkan dedikasi terhadap perilaku tersebut.

Variabel Terikat (X)
Tingkat Psychological Well-Being
1. Penerimaan diri
2. Hubungan positif dengan orang
$\quad$ lain
3. Otonomi
4. Penguasaan terhadap
lingkungan
5. Tujuan hidup
6. Pertumbuhan pribadi

Gambar 1. Kerangka Konseptual
Variabel Terikat (Y)

Tingkat Dedikasi Guru

1. Pasokan energi yang berlimpah

2. Kesediaan untuk berkorban

3. Selalu ingin memberi yang terbaik 


\section{Metode Penelitian}

Metodologi penelitian yang digunakan adalah kuantitatif. Penelitian ini merupakan penelitian regresi. Populasi yang dijadikan sampel pada penenlitian ini adalah seluruh guru SMAN " $X$ " dengan jumlah 62 responden.Pada penelitian ini digunakan probability sampling dengan teknik simple random sampling. Adapun teknik pengumpulan data yang digunakan adalah kuisioner dengan pengukuran skala likert. Sedangkan teknik analisis data yang digunakan peneliti adalah analisis regresi sederhana dengan bantuan program aplikasi komputer berbasis SPSS for windows versi 16.00 untuk membuktikan keabsahan data.

\section{Hasil dan Pembahasan}

Hasil analisis item didapatkan 47 item yang sahih dari 64 item pada variabel tingkat psychological well-being.Item sahih karena memenuhi koefisien korelasi minimal 0,30. Item sahih ditunjukkan dari nilai r yang berkisar 0,3-0,6. Adapun 23 item sahih dari 36 item pada variabel tingkat dedikasi guru.Item sahih ditunjukkan dari nilai $r$ yang berkisar $0,3-0,5$ kurang dari rentang nilai tersebut dianggap gugur.Hasil analisis pada instrumen tingkat psychological wellbeingditemukan nilai reliabilitas sebesar 0,888 yang artinya reliabel. Sedangkan hasil analisis pada instrumen tingkat dedikasi guru ditemukan nilai reliabilitas sebesar 0,781 yang artinya reliabel.

Tabel 3. Hasil Uji Linearitas

\begin{tabular}{|c|c|c|c|c|c|c|}
\hline & & $\begin{array}{l}\text { Sum of } \\
\text { Squares }\end{array}$ & df & Mean Square & $\mathrm{F}$ & Sig. \\
\hline Dedikasi_Guru * & $\begin{array}{l}\text { Between } \\
\text { Groups }\end{array}$ & 4617.177 & 44 & 104.936 & 1.981 & .063 \\
\hline \multirow[t]{2}{*}{ Psikological_Well_Being } & Within Groups & 900.500 & 17 & 52.971 & & \\
\hline & Total & 5517.677 & 61 & & & \\
\hline
\end{tabular}

Hasil uji linearitas dapat diketahui bahwa nilai signifikansi pada Linearity sebesar 0,063. Oleh karena signifikansi lebih dari 0,05 maka dapat disimpulkan bahwa antara variabel tingkat psychological well-beingdengan tingkat dedikasi guru terdapat hubungan yang linear (Priyatna, 2008:35).

Hasil analisis dari korelasi product momentsebagaimana tabel 4 . menunjukkan nilai $\mathrm{r}=0,709, \quad \mathrm{p}=0,000$ pada Sig. (2-tailed), yang berarti korelasinya signifikan karena lebih kecil dari $0,05(\mathrm{p}<0,05)$.Korelasi tersebut dapat disimpulkan bahwa terdapat hubungan yang signifikan tingkat psychological well-beingterhadap tingkat dedikasi guru.

Tabel 4. Hasil Uji Korelasi

\begin{tabular}{llcc}
\hline & & \multicolumn{2}{c}{ Psikological_We } \\
& & 1l_Being & Dedikasi_Guru \\
\hline Psikological_Well_Being & Pearson Correlation & 1 & $.709^{* *}$ \\
& Sig. (2-tailed) & & .000
\end{tabular}




\begin{tabular}{llcc} 
& N & 62 & 62 \\
Dedikasi_Guru & Pearson Correlation & $.709^{* * *}$ & 1 \\
& Sig. (2-tailed) & .000 & \\
& N & 62 & 62 \\
\hline
\end{tabular}

**. Correlation is significant at the 0.01 level (2-tailed).

Tabel 6. Hasil Uji Regresi Linear

\begin{tabular}{ccccccc}
\hline \multicolumn{1}{l}{ Model } & Sum of Squares & df & Mean Square & F & Sig. \\
\hline 1 & Regression & 2773.880 & 1 & 2773.880 & 60.658 & $.000^{\mathrm{a}}$ \\
& Residual & 2743.797 & 60 & 45.730 & & \\
Total & 5517.677 & 61 & & & \\
\hline
\end{tabular}

a. Predictors: (Constant), Psikological_Well_Being

Tabel 7. Coefficients ${ }^{\mathrm{a}}$

\begin{tabular}{|c|c|c|c|c|c|c|}
\hline & \multirow{2}{*}{ Model } & \multicolumn{2}{|c|}{$\begin{array}{l}\text { Unstandardized } \\
\text { Coefficients }\end{array}$} & \multirow{2}{*}{$\begin{array}{c}\text { Standardized } \\
\text { Coefficients }\end{array}$} & \multirow[t]{2}{*}{$\mathrm{t}$} & \multirow[t]{2}{*}{ Sig. } \\
\hline & & B & Std. Error & & & \\
\hline \multirow[t]{2}{*}{1} & (Constant) & 25.023 & 7.086 & & 3.531 & .001 \\
\hline & $\begin{array}{l}\text { Psikological_Well_Bei } \\
\text { ng }\end{array}$ & .357 & .046 & .709 & 7.788 & .000 \\
\hline
\end{tabular}

a. Dependent Variable:Dedikasi_Guru

Pada tabel Coefficients, Unstandardized CoefficientB, diketahui nilai konstanta adalah 25.023, maka model persamaan garis regresi menggunakan metode kuadrat terkecil (least aquares method) yang didapat adalah y $=25.023+$ $357 x$. Pada Anovanilai $F=60.658$ untuk derajat kebebasan $k=1$ dan $n-k-1=62-1$ $1=60$ dan $P$-value $=0,000$ yang jauh lebih kecil dari $\alpha=0,05$. Hal tersebut berarti menu bahwa persamaan regresi secara statistik signifikan untuk memprediksi dedikasi guru dengan prediktor psychological well-being.

Pada tabel Coefficients, nilai t statistik untuk variabel tingkat psychological well-beingsebesar 7.788 dengan nilai $\mathrm{p}=0,00<0,05$. Hal tersebut berarti bahwa ada pengaruh yang signifikan tingkat psychological well-beingterhadap tingkat dedikasi guru.Koefisien determinasi $\left(r^{2}\right)$ dari $r=0,709^{2}=0,503$. Artinya $r^{2}=$ 0,503 (50,3\%), menginformasikan bahwa sumbangan tingkat psychological wellbeing terhadap tingkat dedikasi guru sebesar 50,3\%, sedangkan sisanya 49,7\% dipengaruhi variabel lain yang tidak diteliti.

Berikut ini disajikan tabel sebaran sikap dan perilaku yang menunjukkan kondisi tingkat psychological well-being guru terhadap tingkat dedikasi guru SMAN "X".

Tabel 8. Item Tingkat Psychological Well-Being yang Prosentasenya Paling Banyak Dipilih 


\begin{tabular}{|c|c|c|c|c|c|c|}
\hline \multirow{2}{*}{ No } & \multirow[b]{2}{*}{ Indikator } & \multirow{2}{*}{$\begin{array}{l}\text { No } \\
\text { item }\end{array}$} & \multirow[b]{2}{*}{ Pernyataan } & \multicolumn{2}{|c|}{ Presentase } & \multirow[b]{2}{*}{ Total } \\
\hline & & & & $\begin{array}{l}\text { SS } \\
(5)\end{array}$ & $\begin{array}{c}S \\
(4)\end{array}$ & \\
\hline 1 & Penerimaan Diri & 36 & $\begin{array}{l}\text { Saya menjalani kehidupan } \\
\text { yang ada dengan rasa } \\
\text { bahagia }\end{array}$ & 41,9 & 48,4 & 90,3 \\
\hline 2 & $\begin{array}{l}\text { Pertumbuhan } \\
\text { Pribadi }\end{array}$ & 31 & $\begin{array}{l}\text { Saya mengetahui apa yang } \\
\text { terbaik untuk diri saya } \\
\text { pribadi }\end{array}$ & 33,9 & 59,7 & 93,6 \\
\hline 3 & Penerimaan diri & 3 & $\begin{array}{l}\text { Saya bersyukur pada } \\
\text { keadaan diri }\end{array}$ & 58,1 & 38,7 & $96,8 \%$ \\
\hline
\end{tabular}

Berdasarkan tabel 25 di atas, menunjukkan bahwasanya tingkat psychological well-beingyang paling tinggi adalah item 31 sejumlah $93 \%$ dan item 3 sebanyak 96\%. Hal itu menunjukkan bahwa lebih dari 90\% berada dalam kondisi penerimaan diri dan pertumbuhan pribadi yang maksimal. Hal ini sesuai dengan teori Ryff, (Sarungallo, S. 2009:30-31), individu berusaha berpikiran positif tentang dirinyameskipun mereka sadar akan keterbatasan-keterbatasan dirinya (penerimaan diri), dan mengembangkan bakat dan kemampuan secara optimal (pertumbuhan pribadi) merupakan yang paling utama dalam kesejahteraan psikologis.

Tabel 26. Item Yang Bertolak Belakang dengan Indikator Psychological Well Being yang Sebagian Besar Sesuai dengan Responden

\begin{tabular}{|c|c|c|c|c|c|c|}
\hline \multirow[b]{2}{*}{ No. } & \multirow{2}{*}{\multicolumn{2}{|c|}{$\begin{array}{l}\text { No. } \\
\text { Item }\end{array}$}} & \multirow[b]{2}{*}{ Pernyataan } & \multicolumn{2}{|c|}{ Prosentase } & \multirow[b]{2}{*}{ Total } \\
\hline & & & & $\begin{array}{l}\text { SS } \\
(1)\end{array}$ & $\begin{array}{l}S \\
(2)\end{array}$ & \\
\hline 1 & $\begin{array}{l}\text { Hubungan Positif } \\
\text { dengan Orang Lain }\end{array}$ & 12 & $\begin{array}{l}\text { Saya terganggu jika ada } \\
\text { yang membutuhkan } \\
\text { bantuan }\end{array}$ & 66,1 & 24,2 & $90,3 \%$ \\
\hline 2 & Penerimaan Diri & 35 & $\begin{array}{l}\text { Saya menyesali keadaan } \\
\text { diri sendiri }\end{array}$ & 64,5 & 25,8 & $90,3 \%$ \\
\hline 3 & $\begin{array}{l}\text { Hubungan Positif } \\
\text { dengan Orang Lain }\end{array}$ & 8 & $\begin{array}{l}\text { Saya berat hati saat } \\
\text { harus memberikan } \\
\text { bantuan saat orang lain } \\
\text { dilanda kesusahan }\end{array}$ & 69,4 & 24,2 & 93,6 \\
\hline 4 & $\begin{array}{l}\text { Hubungan Positif } \\
\text { dengan Orang Lain }\end{array}$ & 6 & $\begin{array}{l}\text { Saya terisolir dari } \\
\text { pergaulan yang ada }\end{array}$ & 80,6 & 17,7 & $98,3 \%$ \\
\hline
\end{tabular}

Berdasarkan tabel 26 di atas, menunjukkan bahwa indikator tingkat psychological well-beingyang paling banyak dipilih oleh responden adalah indikator hubungan positif dengan orang lain, pertumbuhan pribadi dan penerimaan diri. Indikator hubungan positif dengan orang lain: Item 6 memuat pernyataan Saya terisolir dari pergaulan yang ada, item dipilih sebanyak 98,3\%. Item 8 memuat pernyataan: Saya berat hati saat harus memberikan bantuan saat orang lain dilanda kesusahan, item dipilih sebanyak 93,6\%. Item 12 memuat 
pernyataan saya terganggu jika ada yang membutuhkan bantuan. Item dipilih sebanyak $90,3 \%$.

Item-item di atas menunjukkan bahwa ada hubungan yang kurang sehat antara satu guru dengan guru yang lainnya. Kondisi ini membuat guru menjadi individual dan tidak memiliki kompromi jika terjadi konflik. Ryff menjelaskan hal ini melalui pernyataannya (Utamaya, R. 2009:26-31), bahwa kemampuan membina hubungan baik dengan orang lain meliputi kemampuan untuk membina hubungan interpersonal yang hangat dan saling percaya, saling mengembangkan pribadi satu sama lain serta mampu menjalin persahabatan yang mendalam.

Sementara itu individu yang tidak memiliki hubungan positif dengan orang lain digambarkan memiliki sedikit hubungan yang dekat dan saling percaya dengan orang lain, sulit untuk bersikap hangat, terbuka, dan peduli terhadap orang lain, terisolasi dan merasa tertekan dalam membina hubungan interpersonal, serta tidak bersedia berkompromi untuk mempertahankan ikatan yang penting dengan orang lain.

Indikator penerimaan diri: item 35 memuat pernyataan Saya menyesali keadaan diri sendiri, dipilih sebanyak 90,3\%. Hal ini menunjukkan bahwa ada sebagian guru yang belum merasa berbahagia dengan diri sendiri. Dasar orang untuk bisa berbahagia adalah jika dia mampu menerima diri dengan baik. Dengan pengertian mengolah segala kekurangan dan mengembangkan segala kelebihan dengan kesadaran bahwa semua orang juga memiliki kekurangan dan kelebihan sehingga tidak senantiasa mencela kepribadiannya sendiri.

Riff menyatakan (Utamaya, R. 2009:26-31): penerimaan diri merupakan ciri sentral dari konsep kesehatan mental dan karakteristik dari individu yang teraktualisasi, berfungsi secara optimal dan matang. Individu yang dapat menerima dirinya sendiri adalah individu yang memiliki sikap positif terhadap diri sendiri, mengakui dan menerima berbagai aspek diri termasuk kualitas baik dan buruk, dan merasa positif dengan kehidupan yang dijalani. Sebaliknya, individu dikatakan tidak dapat menerima dirinya dengan baik adalah individu yang merasa tidak puas dengan dirinya, kecewa dengan apa yang terjadi pada masa lalu, merasa bermasalah dengan beberapa aspek tertentu dari kualitas pribadi, dan berharap menjadi seseorang yang berbeda dari dirinya pada saat ini.

Tabel 27. Item Tingkat Dedikasi Guru Yang Banyak Dipilih

\begin{tabular}{|c|c|c|c|c|c|c|}
\hline \multicolumn{4}{|c|}{ No. } & \multicolumn{3}{|c|}{ Prosentase } \\
\hline No. & Indikator & Item & Pernyataan & $\begin{array}{l}\text { SS } \\
(5)\end{array}$ & $\begin{array}{c}S \\
(4)\end{array}$ & Total \\
\hline 1 & Kepuasan Hati & 22 & $\begin{array}{l}\text { Saya merasa lega melihat nilai } \\
\text { siswa pada pelajaran saya } \\
\text { tuntas semua }\end{array}$ & 46,8 & 43,5 & $90,3 \%$ \\
\hline 2 & Kebahagiaan & 7 & $\begin{array}{l}\text { Saya merasa bahagia menjadi } \\
\text { guru pada sekolah ini }\end{array}$ & 38,7 & 53,2 & $91,9 \%$ \\
\hline
\end{tabular}




\begin{tabular}{rlcllll}
\hline 3 & Kebahagiaan & 26 & $\begin{array}{l}\text { Saya merasa bahagia saat } \\
\text { berada di tengah-tengah siswa }\end{array}$ & 48,4 & 45,2 & $93,6 \%$ \\
4 & Kepuasan Hati & 24 & $\begin{array}{l}\text { Saya puas ketika melihat } \\
\text { siswa lolos seleksi di berbagai } \\
\text { perguruan tinggi negeri }\end{array}$ & 61,3 & $35,5 \quad 96,8 \%$ \\
& & & & \\
\hline
\end{tabular}

Berdasarkan tabel 27 di atas, menunjukkan bahwasanya tingkat dedikasi guru yang paling tinggi ada pada indikator Kepuasan Hati dan Kebahagiaan. Indikator Kepuasan Hati dengan item 22 sejumlah 90,3\% item dan item 24 sebanyak 96,8\% .Indikator Kebahagiaan ada pada item 7 sebanyak 91,6\%, item 26 sebanyak 93,6\%, dan item 28 sebanyak 88,7\%.

Sebaran indikator dengan pilihan tertinggi tampak bahwa kebahagiaan dalam menjalani profesi pilihan memberikan hasil kepuasan hati atas dedikasi yang dilakukan dengan sepenuh hati dan penuh rasa cinta. Hal ini sesuai dengan teori Munir, A. (2006;102-105) yang menjelaskan bahwa dedikasi dan cinta seorang guru terhadap profesi dan anak-anak didiknya dapat ditengarahi dari; pasokan energi yang berlimpah, kesediaan berkorban, dan selalu ingin memberi yang terbaik.Dalam hal ini Kaswan (2015:170) menambahkan, "dedikasi ditengarahi oleh perasaan bermakna, semangat, inspirasi, bangga, dan tantangan di tempat bekerja". Perasaan bermakna merupakan kesempatan yang dirasakan seseorang dalam mengejar tujuan yang layak atau mulia. Perasaan bermakna tersebut adalah perasaan seseorang yang orang mencurahkan waktu dan energinya - bahwa dia menjalankan misi berharga dan tujuannya sangat penting dalam konteks yang lebih besar. Aspek lain dari dedikasi adalah rasa bangga. Rasa bangga diasosiasikan dengan kesuksesan, prestasi, dan keanggotaan kelompok. Rasa bangga mendorong perilakuprososial seperti prestasi dan kesuksesan. Selain itu rasa bangga berkaitan dengan berfungsi dan terpeliharanya harga diri.

Tabel 28. Item yang Bertolak Belakang Dengan Indikator Dedikasi Guru yang Sebagian Besar Sesuai Dengan Responden

\begin{tabular}{|c|c|c|c|c|c|c|}
\hline \multirow[b]{2}{*}{ No. } & \multicolumn{3}{|c|}{ No. } & \multicolumn{2}{|c|}{ Presentase } & \multirow[b]{2}{*}{ Total } \\
\hline & Indikator & Item & Pernyataan & $\begin{array}{l}\text { SS } \\
(1)\end{array}$ & $\begin{array}{c}S \\
(2)\end{array}$ & \\
\hline 1 & $\begin{array}{l}\text { Pasokan Energi } \\
\text { yang Berlimpah }\end{array}$ & 8 & $\begin{array}{l}\text { Saya merasa terabaikan } \\
\text { saat berada diantara siswa }\end{array}$ & 66,1 & $\begin{array}{c}21 \\
0\end{array}$ & $87,1 \%$ \\
\hline 2 & $\begin{array}{l}\text { Pasokan Energi } \\
\text { yang Berlimpah }\end{array}$ & 12 & $\begin{array}{l}\text { Saya merasa menjadi guru } \\
\text { karena pilihan terpaksa }\end{array}$ & 66,1 & $\begin{array}{c}21 \\
0\end{array}$ & $87,7 \%$ \\
\hline 3 & $\begin{array}{l}\text { Selalu Ingin } \\
\text { Memberi Yang } \\
\text { Terbaik }\end{array}$ & 16 & $\begin{array}{l}\text { Saya berharap mendapat } \\
\text { balas jasa dari setiap } \\
\text { perbuatan baik saya pada } \\
\text { sekolah }\end{array}$ & 62,9 & $\begin{array}{c}25 \\
8\end{array}$ & $88,7 \%$ \\
\hline 4 & $\begin{array}{l}\text { Selalu Ingin } \\
\text { Memberi Yang } \\
\text { Terbaik }\end{array}$ & 18 & $\begin{array}{l}\text { Saya merasa lelah dalam } \\
\text { mengembangkan diri }\end{array}$ & 50,0 & $\begin{array}{c}38 \\
7\end{array}$ & $88,7 \%$ \\
\hline
\end{tabular}




\begin{tabular}{|c|c|c|c|c|c|c|}
\hline 5 & $\begin{array}{l}\text { Pasokan Energi } \\
\text { yang Berlimpah }\end{array}$ & 10 & $\begin{array}{l}\text { Saya merasa kecewa } \\
\text { dengan profesi sebagai } \\
\text { guru }\end{array}$ & 77,4 & $\begin{array}{c}16, \\
1\end{array}$ & $93,5 \%$ \\
\hline 6 & $\begin{array}{l}\text { Pasokan Energi } \\
\text { yang Berlimpah }\end{array}$ & 25 & $\begin{array}{l}\text { Saya merasa kecewa } \\
\text { sebagai guru sekolah ini }\end{array}$ & 82,3 & $\begin{array}{c}14, \\
5\end{array}$ & $96,8 \%$ \\
\hline
\end{tabular}

Berdasarkan tabel 28 di atas, menunjukkan bahwa item tingkat dedikasi guru yang bertolak belakang dengan indikator dedikasiguru yang sebagian besar sesuai dengan responden adalah indikator pasokan energi yang berlimpah dan indikator selalu ingin memberi yang terbaik.

Indikator pasokan energi yang berlimpah ada 4 item dengan prosentase tinggi yakni: item 8 sebanyak 87,1\%, item 10 sebanyak 93,5\%, item 12 sebanyak $87,7 \%$, dan item 25 sebanyak 96,8\%. Item 8 memuat pernyataan: Saya merasa terabaikan saat berada diantara siswa. Dari pernyataan itu menunjukkan bahwa sebanyak $87,1 \%$ guru SMAN"X" merasa tidak nyaman (terabaikan) saat sedang bersama siswanya. Jika seorang guru merasa terabaikan oleh siswa yang merupakan subyek didik dari profesinya itu menunjukkan bahwa tidak ada perasaan bermakna saat sedang melaksanakan proses pembelajaran maupun saat di luar pembelajaran. Dalam hal ini Kaswan (2015:170) menyatakan, "dedikasi ditengarahi oleh perasaan bermakna, semangat, inspirasi, bangga, dan tantangan di tempat bekerja". Perasaan bermakna merupakan kesempatan yang dirasakan seseorang dalam mengejar tujuan yang layak atau mulia. Perasaan bermakna tersebut adalah perasaan dimana orang ada dalam jalur dimana orang layak mencurahkan waktu dan energinya - bahwa dia menjalankan misi yang berharga dan tujuannya sangat penting dalam konteks yang lebih besar. Aspek lain dari dedikasi adalah rasa bangga. Rasa bangga diasosiasikan dengan kesuksesan, prestasi, dan keanggotaan kelompok. Rasa bangga mendorong perilaku prososial seperti prestasi dan kesuksesan. Selain itu rasa bangga berkaitan dengan berfungsi dan terpeliharanya harga diri.

Fathurrohman, (2012:13) menambahkan bahwa guru adalah ujung tombak dalam proses belajar mengajar. Guru berinteraksi langsung dengan siswa dalam kelas. Guru memegang peranan sangat penting dalam membuat siswa mengerti dan paham mengenai mata pelajaran yang diajarkan. Sekolah sebagai institusi pendidikan membutuhkan guru yang tidak hanya berfungsi sebagai pengajar yang mengajarkan mata pelajaran tertentu kepada peserta didiknya, tetapi jugasebagai pendidik yang memberikan bekal pengetahuan kepada siswanya mengenai etika, kemampuan survive dalam hidup, moral, empati, kreasi dan sebagainya.

Item 10 memuat pernyataan: Saya merasa kecewa dengan profesi sebagai guru. Sebanyak 93,5\% guru SMAN " $X$ " yang diteliti memberikan pernyataan demikian. Tentu saja hal ini dapat mengganggu interaksi antara guru dan siswa. Guru adalah sebuah profesi, tetapi pengabdiannya memerlukan rasa cinta yang demikian mendalam. Munir, A. (2006;102-105) menjelaskan bahwa cinta adalah 
dasar utama dalam sebuah pengabdian. Melalui sebuah cinta seseorang akan bisa melakukan apapun tanpa ada paksaan dari siapapun. Demikian pula dalam dedikasi terhadap profesi pilihannya.

Item 12 memuat pernyataan:Saya merasa menjadi guru karena pilihan terpaksa. Ada sekitar 87,7\% guru SMAN "X" memilih pernyataan tersebut. Hal ini tentu sangat berdampak pada kinerja. Subini (2012:49-50), menyatakan bahwa; banyak faktor yang membuat seseorang memutuskan untuk menjadi guru, tetapi idealnya menjadi guru adalah panggilan hati nurani. Menjadi guru berdasarkan tuntutan pekerjaan adalah suatu perbuatan yang mudah, namun menjadi guru berdasarkan panggilan jiwa tidaklah muda. Guru lebih banyak dituntut sebagai suatu pengabdian kepada anak didik daripada tuntutan pekerjaan dan materi. Kepribadian guru akan tercermin dalam sikap dan perbuatannya dalam membina dan membimbing anak didik.

Item 25 memuat pernyataan: Saya merasa kecewa sebagai guru sekolah ini. Secara teori ada beberapa hal yang membuat seseorang menjadi produktif dalam pekerjaaannya, diantaranya adalah budaya kerja dan kesejahteraan. Budaya kerja adalah berbagai kebiasaan positif yang dilakukan oleh seorang guru ketika melaksanakan tugasnya di sekolah. Adapun yang dimaksud dengan kesejahteraan tidak hanya yang berhubungan dengan honor saja, tetapi terkait pula dengan kenyamanan dan keamanan guru dalam bertugas serta kesehatan guru. Kesejahteraan menjadi salah satu yang mempengaruhi tinggi-rendahnya kinerja guru. Dengan kesejahteraan yang tinggi kebutuhan fisik dan psikis dapat terpenuhi. Kesejahteraan guru yang tinggi juga dapat meningkatkan harkat dan martabat di tengah masyarakat (Ardi W.N. 2015:40-54).

Indikator selalu ingin memberi yang terbaik terdapat 2 item yaitu 16 dan 18 dengan jumlah responden tinggi. Item 16 memuat pernyataan: Saya berharap mendapat balas jasa dari setiap perbuatan baik saya pada sekolah. Item tersebut dipilih sebanyak $88,7 \%$. Pernyataan itu mewakili dari kurangnya rasa berkorban terhadap profesi yang sedang dijalaninya. Hal ini tidak sejalan dengan penjelasan Rahman, M ( 2014-201) bahwa dalam melaksanakan tugas pengabdian pada masyarakat hendaknya didasari atas dorongan atau panggilan hati nurani, sehingga guru akan merasa senang dalam melaksanakan tugas berat mencerdaskan anak didik. Zahroh (2015:39) menambahkan bahwa melalui dedikasi yang dimiliki seorang guru, tidak akan menjadikan profesinya sebagai suatu pekerjaan yang digunakan untuk mencari keuntungan secara material atau finansial saja, melainkan lebih kepada bentuk dan wujud kecintaan terhadap pekerjaan tersebut yang muncul dengan sendirinya, sehingga timbul jiwa pengabdian yang terus menyala bagai api unggun".

Item 18 dari indikator selalu ingin memberi yang terbaik memuat pernyataan: Saya merasa lelah dalam mengembangkan diri. Pernyataan tersebut dipilih sebanyak 88,7\%. Hal in mennjukkan bahwa guru SMAN " $\mathrm{X}$ " belum memiliki motivasi tinggi untuk mengembangkan diri sebagaimana diamanatkan 
dalam UU Pendidkan sebagai guru profesional.UU Guru dan Dosen 2015 pasal 8 menyebutkan bahwa uru wajib memiliki kualifikasi akademik, kompetensi, sertifikat pendidik, sehat jasmani dan rohani serta memiliki kemampuan untuk mewujudkan tujuan pendidikan nasional. Kualifikasi akademik mempunyai makna pengembangan diri yang tiada henti karena perkembangan jaman yang selalu membawa pembaharuan. Jadi guru diwajibkan melakukan pengembangan diri sebagaimana diamantakan oleh UU Pendidikan. Ditekankan pula dalam Prinsip Profesional (pasal 7) yang berbunyi: guru memiliki komitmen untuk meningkatkan mutu pendidikan, keimanan, ketakwaan dan ahlak mulia.

\section{Kesimpulan}

Berdasarkan hasil analisis data dan teknik regresi linear, dari tabel summary menunjukkan bahwa nilai $\mathrm{R}^{2}(R$ Square) sebesar $50,3 \%$ dari variabeltingkat psychological well-being dapat dijelaskan perubahan dalam variabel tingkat dedikasi guru. Tabel anova mengindikasikan bahwa tingkat psychological wellbeing secara statistik signifikan dengan nilai $\mathrm{F}=60.658$ untuk derajat kebebasan $k$ $=1$ dan $n-k-1=62-1-1=60$ dan $P$-value $=0,000$ yang jauh lebih kecil dari $\alpha=$ 0,05. Persamaan garis regresi menggunakan metode kuadrat terkecil (least aquares method) yang didapat adalah y $=25.023+357 \mathrm{x}$.

Hasil analisis data melalui teknik regresi sederhana menunjukkan bahwa nilai t statistik untuk variabel tingkat psychological well-beingsebesar 7.788 dengan nilai $\mathrm{p}=0,00<0,05$. Hal tersebut berarti dapat disimpulkan bahwa ada pengaruh yang positif dan signifikan tingkatpsychological well-beingterhadap tingkat dedikasi guru SMAN "X".

Dari data di atas dapat diketahui jika sumbangantingkat psychological wellbeing dengan tingkat dedikasi guru sebesar 50,3\%. Sedangkan sisanya 49,7\% dipengaruhi variabel lain yang tidak diteliti.

\section{Daftar Pustaka}

Arikunto, S. 2006. Prosedur Penelitian. Suatu pendekatan praktik. Jogjakarta: PT. Rineka Cipta

Azwar, S. 2007. Metode Penelitian. Jogjakarta: Pustaka Pelajar

Barnawi \& Arifin, M.2012. Kinerja guru Profesional. Instrumen pembinaan, peningkatan, dan penilaian. Jogjakarta: Ar-Ruzz Media

Fathurrohman, P. Dan Suryana, A. 2012. Guru Profesional. Bandung: PT Refika Aditama

Giustina, F.I. 2015. Hubungan Antara Kesejahteraan Psikologis Dan Kesesuaian Peran Kerja Dengan Keterikatan Karyawan Pada Karyawan Bagian Produksi PT. Barata Indonesia (Persero). Skripsi, tidak diterbitan. Surabaya: UNESA 
Hamidi, dkk. 2015. Motivasi Guru Bertahan Mengajar Di Daerah terpencil. Jurnal Pendidikan dan Pembelajaran

Harian umum Pelita. 13 Maret 2016. Dedikasi

Ismawati. 2013. Peran Perubahan Organisasi Dengan Kesejahteraan Psikologis (psychological well-being) Karyawan di PT. PLN (Persero) Area malang. Skripsi. UIN Malang

Kaswan. 2015. Sikap Kerja. Dari teori dan implementasi sampai bukti. Bandung: Alfabeta

Kompas online, 24 November 2015(http://www.pelita.or.id/baca.php?id=53501)

Kamus Besar Bahasa Indonesia (KBBI). Definisi Dedikasi. Diunduh pada 24 September 2016, dari www.kbbi.wed.id.

Munir, A. 2006. Spiritual Teaching. Agar guru semakin mencintai pekerjaan dan anak didiknya. Yogyakarta; Pustaka Insan Madani

Materi Diklat. 2008. Penilaian Kinerja Guru. Direktorat Tenaga Kependidikan. Direktorat Jenderal. Peningkatan Mutu Pendidikan dan Tenaga Kependidikan. Departemen Pendidikan Nasional. 2008

Naim, N. 2012. Character Building.optimalisasi peran pendidikan dalam pengembangan ilmu dan pembentukan karakter bangsa. Jogjakarta: ArRuzz Media

Prosiding. 2015. Perkembangan Manusia dan Kesejahteraan Psikologis. Psychology Forum Direktorat Pascasarjana: Universitas Muhammadiyah Malang

Pedoman Lomba Guru Berdedikasi Pendidikan Mennengah Di Daerah Khusus Tingkat Nasional 2014

Rahman, M dan Sofan Amri. 2014. Kode Etik Profesi Guru: Legalitas, Realitas dan Harapan. Wacana Untuk Menunjang dan Menjadikan Guru Profesional. Jakarta: Prestasi Pustakarya

Riawaty, R.R. 2006. Gambaran Psychological Well-Being Pada Wanita Dewasa Madya Yang Menjanda Akibat Suami Meninggal Dunia (Studi Kasus). Skripsi, tidak diterbitkan. Surabaya: Universitas Airlangga

Sari, D.P.P. 2006. Kesejahteraan Psikologis (Psychological Well-Being) Lansia Yang Berstatus Duda Pasca Kematian Pasangan. Skripsi, tidak diterbitkan. Surabaya: Universitas Airlangga

Sarungallo, E. 2009. Hubungan Anatara Dukungan Sosial Dengan Psychological Well-Being Pada Orangg Dengan HIV/AIDS (ODHA). Skripsi, tidak diterbitkan. Surabaya: Universitas Airlangga

Seligman, M. 2013. Beyond Authentic Happiness.Menciptakan Kebahagiaan Sempurna Dengan Psikologi Positif. Bandung: PT Mizan Pustaka

Sopiah. 2008. Perilaku Organisasional. Yogyakarta: CV Andi Offset

Subini, N., 2012. Awas, Jangan Jadi Guru Karbitan. Jakarta; Javalitera

Sugiyono. 2009. Metode Penelitian Kuantitatif Kualitatif dan R\&D. Bandung: Alfabeta 
Sugiyono. 2010. Metode Penelitian Kuantitatif Kualitatif dan R\&D. Bandung: Alfabeta

Sugiyono. 2011. Metode Penelitian Kuantitatif Kualitatif dan R\&D. Bandung: Alfabeta

Supardi. 2014. Kinerja Guru. Jakarta: PT Raja Grafindo Persada

Tasmara, T. 2004. Membudayakan Etos Kerja Islami. Jakarta: Gema Insani

Undang-undang Republik Indonesia Nomor 14 Tahun 2005, Guru dan Dosen. 30 Desember 2008. Lembaran Negara Republik Indonesia Tahun 2005 Nomor 157. Jakarta

Uno, B.H. 2012. Profesi Kependidikan. Problema, solusi, dan reformasi pendidikan di Indonesia. Jakarta: PT Bumi Aksara

Utamaya, R.2009. Hubungan Antara Sosial Dengan Psychological Well-Being Pada Penderita Kanker Payudara Pasca Mastektomi. Skripsi, tidak diterbitkan. Surabaya: Universitas Airlangga

Wahyudi, Imam. 2012. Mengejar Profesionalisme Guru. Jakarta: Prestasi Pustakarya

Wibowo. 2014. Perilaku Dalam Organisasi. Jakarta: PT Raja Grafindo Persada Qomariah, R.S., dkk. 2015. Psychological Well-Being Perempuan Buruh Bangunan. Jurnal. Seminar Psikologi dan Kemanusiaan. UMM

Zahro, A. 2015. Membangun Kualitas Pembelajaran Melalui Dimensi Profesionalisme Guru. Bandung: CV Yrama Widya. 